\title{
Bioavailability of heavy metals and polycyclic aromatic hydrocarbon in long-term sewage-drained soils of Tamil Nadu
}

\author{
Veeramani Kathavarayan ${ }^{1, *}$, S. Avudainayagam", K. Sara Parwin Banu', \\ N. Chandrasekharan ${ }^{2}$, S. Karthikeyan ${ }^{3}$, K. Bhuvaneswari ${ }^{4}$ and P. T. Ramesh ${ }^{1}$ \\ ${ }^{1}$ Department of Environmental Science, ${ }^{2}$ Department of Soil Science and Agricultural Chemistry, ${ }^{3}$ Department of Bioenergy, \\ ${ }^{4}$ Department of Agricultural Entomology, Tamil Nadu Agricultural University, Coimbatore 641 003, India
}

Heavy metals and organic contaminants are reported in sewage discharged sites. Screening and assessment of their toxic concentration in soils of the discharged sites of major cities in Tamil Nadu, India have been carried out in the present study. The major cities included Coimbatore (Ukkadam; U), Madurai (Avanaiyapuram; A), Tiruchirappalli (Rettamalai; R), Nesapakkam (N) and Koyambedu (K) Chennai Corporation. The total aquaregia-extractable concentrations of cadmium, chromium, lead and nickel were measured and found to be highest in $U$, followed by $A$, $R$, $N$ and $K$. Their potential bioavailabilities were quantified in the following order: $\mathrm{Cd}-\mathrm{N}>\mathrm{U}>$ $\mathbf{K}>\mathbf{R}>\mathbf{A} ; \mathbf{C r}-\mathbf{N}>\mathbf{A}>\mathbf{K}>\mathbf{R}>\mathbf{U} ; \mathbf{P b}-\mathbf{N}>\mathbf{K}>\mathbf{R}$; $\mathbf{U}>\mathbf{A} ; \mathbf{N i}-\mathbf{N}>\mathbf{K}>\mathbf{R}>\mathbf{U}>\mathbf{A}$. Bioavailable Factor was found to be highest for $\mathrm{Cd}$ in $\mathrm{U}(2.9 \%-83 \%)$ followed by $\mathrm{Cr}$ in $\mathrm{N}(1.1 \%-62.3 \%)$ and $\mathrm{Ni}$ in $(1.70 \%-$ $52.7 \%$ ) N. With regard to organic contamination, the major pesticides belonged to 13 organochlorine, 10 organophosphate and 8 synthetic pyrethroids reported below detectable concentration. Among the 16 US EPA priority poly aromatic hydrocarbon (PAHs) only 15 were detected. However, PAHs were found to be less than the permissible concentration for soils $\left(0.3 \mathrm{mg} \mathrm{kg}^{-1}\right)$ in sewage-contaminated sites. The results show that there is potential risk of transfer of heavy metals to higher trophic level of the food chain.

Keywords: Heavy metals, health risk, polycyclic aromatic hydrocarbon, sewage contamination.

SEWAGE-DRAINED soils have a number of organic and inorganic chemical substances. Soil discharged with sewage effluent becomes a major sink of pollutants. The sewage effluent is increasingly utilized for raising crops due to demand for irrigation water. It is estimated that about 73,000 ha of peri-urban land is irrigated with wastewater in India ${ }^{1}$. For example, in the downstream rural area of Vadodara, Gujarat, wastewater irrigation

*For correspondence. (e-mail: veeraens@gmail.com) supports annual agricultural production worth Rs 266 million ${ }^{1}$. According to an estimate, about 38,354 million litres per day (MLD) sewage was produced but only 11,786 MLD was treated and the remaining let out indiscriminately to open lands ${ }^{2}$. India has $17.74 \%$ of the world population ${ }^{3}$ with an annual increase of $1.11 \%$ which demand 277 and 318 metric tonnes of food grains by the year 2020 and 2040 respectively (http://www.foodsecurityportal.org/india). Due to the shortage of irrigation water, sewage effluent is also used for its nutrient content, as it can supplement about $25 \%-50 \%$ of nitrogen and phosphorus fertilizers ${ }^{4}$. It has been estimated that in India sewage can irrigate around $1-1.5 \mathrm{~m}$ ha of land annually and has a potential to contribute about 1 million tonnes of plant nutrients ${ }^{5}$. Sewage irrigation is a doublesided sword. The untreated sewage irrigation benefits the soil with organic matter and plant nutrients namely nitrogen and phosphorus. However, continuous irrigation adds recalcitrant organic and inorganic pollutants to the soil ${ }^{6-8}$. For instance, about 47 chemical analytes belonging to pesticides, pharmaceuticals, personal care-products, phenolic estrogens, antioxidants and disinfection by-products were detected in soils irrigated with sewage 9 . A wide range of chemical substances were screened in sewage sludge when applied as manure ${ }^{10-13}$. Polycyclic aromatic hydrocarbons (PAHs) are among the major organic pollu$\operatorname{tants}^{14,15}$. Around $1.4-33 \mathrm{mg} \mathrm{kg}^{-1}$ of PAHs has been reported in sewage-drained soils ${ }^{16}$. PAHs are a matter of concern due to their carcinogenic and mutagenic properties $^{17}$. Several PAHs have been identified by the United Nations Environment Programme ${ }^{18}$ as pollutants of global concern posing potential risks to human health and the environment. Although several thousands of PAHs exist, only 16 assigned by the United States Environmental Protection Agency (US EPA) as priority pollutants are usually analysed in soil and other environmental samples (Table 1; http://www.epa.gov/osw/hazard/wastemin/ priority.htm). The International Agency for Research on Cancer $^{19}$ has classified PAHs as Group 1, 2A or 2B hazardous. Few of them are benzo $\alpha$-pyrene (Group 1), naphthalene, chrysene, benzo $(\alpha)$ anthracene, benzo $(k)$ fluoranthene and benzo $(\beta)$ fluoranthene (Group 2B) ${ }^{19}$. 


\section{RESEARCH ARTICLES}

Table 1. List of environmentally important polycyclic aromatic hydrocarbon and their toxicological properties

\begin{tabular}{|c|c|c|c|c|c|}
\hline PAHs & Molecular structure & Molecular weight & $\begin{array}{c}\text { Water solubility }\left(\mathrm{mg} \mathrm{kg}^{-1}\right. \\
\text { unless otherwise } \\
\text { mentioned) }\end{array}$ & $\begin{array}{c}\text { Half-life (days) } \\
\text { (days, unless otherwise } \\
\text { mentioned) }\end{array}$ & $\begin{array}{l}\text { Toxicity equivalent } \\
\text { factor }^{52}\end{array}$ \\
\hline Nap & & 128.17 & 31.6 & $<125$ (ref. 50) & 0.001 \\
\hline Ace & & 152.196 & Insoluble & 25 days & 0.001 \\
\hline Ac & & 154.2 & 3.90 & $\begin{array}{c}20 \text { days } \\
\text { (Biological half life) } \\
(\text { refs } 50,51)\end{array}$ & 0.001 \\
\hline Phe & & 178.23 & 1.60 & 25-2080 (ref. 50) & 0.001 \\
\hline An & & 178.23 & 0.044 & 110-180 (ref. 50) & 0.01 \\
\hline Flu & & 202.26 & 26.50 & 44-322 (ref. 50) & 0.001 \\
\hline Py & & 202.25 & 0.135 & 199-260 (ref. 50) & 0.001 \\
\hline $\mathrm{Cy}$ & & 228.29 & 0.0002 & $371-387$ (ref. 50) & 0.01 \\
\hline $\mathrm{BbF}$ & & $252.3 b$ & 0.0015 & 211-294 (ref. 50) & 0.1 \\
\hline $\mathrm{BkF}$ & & 252.3 & 0.00076 & $21,840-51,360 \mathrm{~h}$ & 0.1 \\
\hline $\mathrm{BaP}$ & & 252.3 & $2 \times 10^{-8}$ to $62 \times 10^{-7}$ & 229-309 (ref. 50) & 1.0 \\
\hline $\mathrm{Da}, \mathrm{hA}$ & & 278.35 & $2.49 \times 10^{-3}$ & $361-420$ (ref. 50) & 0.1 \\
\hline BghiP & & 276.34 & $2.6 \times 10^{-4}$ & $<3468$ (ref. 50) & 0.01 \\
\hline $\mathrm{I} 1,2,3-\mathrm{cdP}$ & & 276.3 & $1.9 \times 10^{-4}$ & 730 days (ref. 51) & 0.01 \\
\hline
\end{tabular}




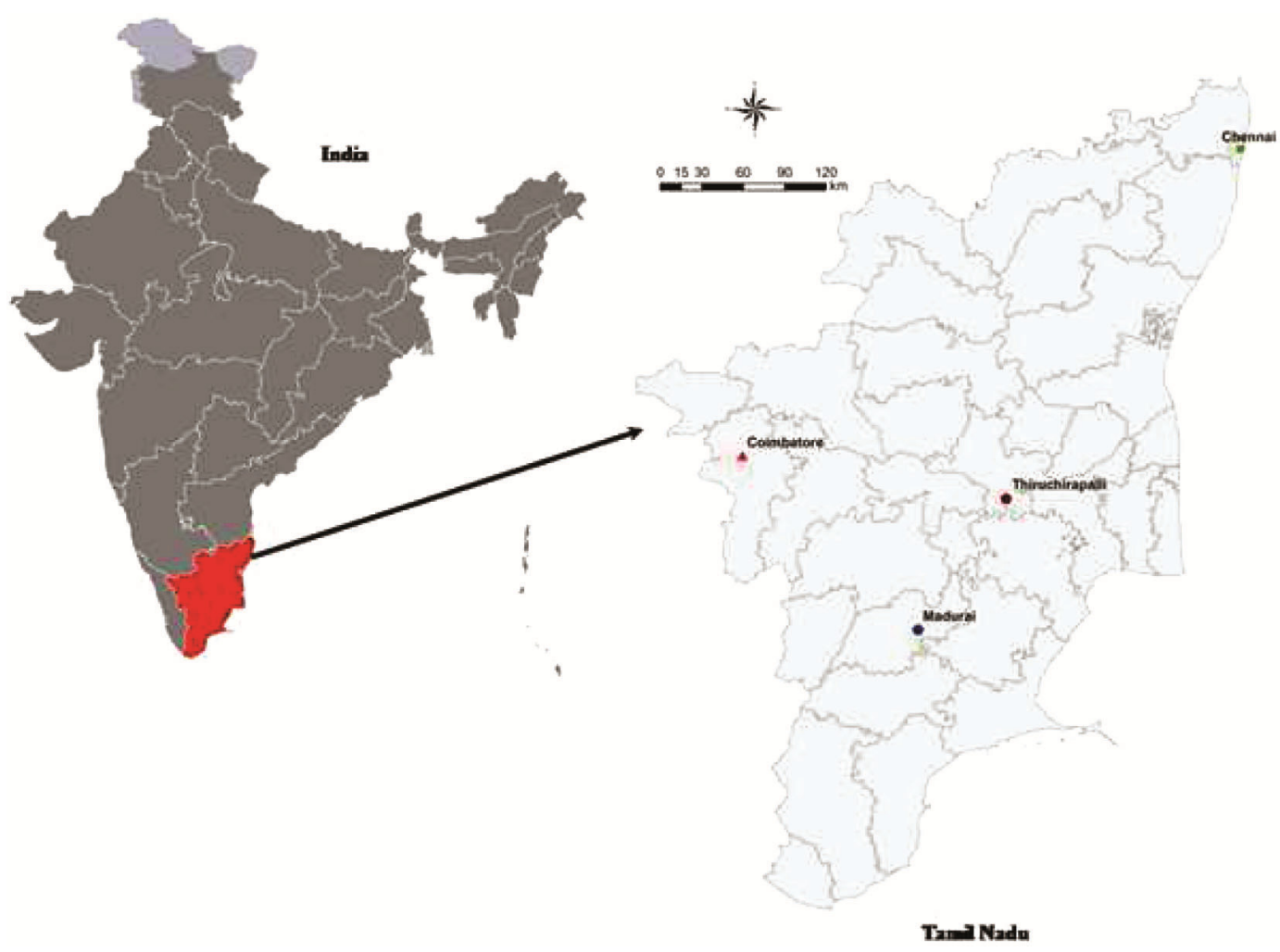

Figure 1. Map showing sampling sites of major cities in Tamil Nadu, India.

The most significant health effect due to exposure to PAHs is the risk of lung cancer ${ }^{20}$.

Generally, sewage irrigated soils are enriched with few heavy metals, namely cadmium $(\mathrm{Cd})$, chromium $(\mathrm{Cr})$, copper $(\mathrm{Cu})$, lead $(\mathrm{Pb})$ and nickel $(\mathrm{Ni})$ which commonly coexist with PAHs at minimal concentration ${ }^{21,22}$. The health effects of some heavy metals are well established arsenicosis (As), itai itai (Cd), pulmonary sensitization and liver damage $(\mathrm{Cr})$, minamata $(\mathrm{Hg})$, brain and central neural damage $(\mathrm{Pb})$, and allergic contact dermatitis $(\mathrm{Ni})$. Several remedial options tested for heavy metals coexisting with organic chemical substances showed that bioremediation effectively degraded PAHs in the presence of heavy metals ${ }^{21-27}$. Recent studies have reported that arsenic (As), Cd, cobolt (Co), $\mathrm{Cr}, \mathrm{Cu}$, mercury ( $\mathrm{Hg}$ ), $\mathrm{Pb}, \mathrm{Ni}$ and zinc $(\mathrm{Zn})$ are the prominent heavy elements in those soils $^{21,28-30}$. Toxicological experiments on $\mathrm{Zn}, \mathrm{Cr}, \mathrm{Cu}, \mathrm{Ni}$, $\mathrm{Co}$ and $\mathrm{Pb}$ in soils reported that they had high hazard quotient (HQ) which could adversely affect soil health ${ }^{31}$. In this context, environmental research on versatile contamination in soil is gaining its momentum in India. To address this kind of mixed contamination in soil, the present study was carried out with the following objectives. First, assess the heavy metals and organic contaminations, namely insecticides and PAHs in sewage soils. Secondly, quantify toxic heavy metals as their concentrations directly influence the microbial degradation of organic contamination in soil. Lastly, examine the toxic concentration of heavy metals with respect to soil quality parameters.

\section{Materials and methods}

\section{Sampling site}

The sampling sites of sewage-contaminated soils are Ukkadam (U) in Coimbatore $\left(11.068^{\circ} \mathrm{N}, 76.955^{\circ} \mathrm{E}\right)$, Avaniyapuram (A) in Madurai $\left(9.925^{\circ} \mathrm{N}, 78.119^{\circ} \mathrm{E}\right)$, Rettamalai (R) in Tiruchirappalli $\left(10.790^{\circ} \mathrm{N}, 78.704^{\circ} \mathrm{E}\right)$, and Koyambedu (K) and Nesapakkam (N) in Chennai $\left(13.082^{\circ} \mathrm{N}, 80.270^{\circ} \mathrm{E}\right)$ (Figure 1).

\section{Collection of soil and processing}

' $\mathrm{V}$ ' shaped pits were made using steel spade at a depth of more than $30 \mathrm{~cm}$ in the sampling sites. Around $1 \mathrm{~kg}$ of soil samples were scooped from both sides of the shaped pit. The soil samples were collected during early February of 2016. The collected samples were packed in airtight polyethylene bags and transported to the laboratory. Next, the samples were air-dried for 3-5 days and then smashed with a wooden mallet to powder them. The powdered samples were sieved through $2 \mathrm{~mm}$ sieve and a portion of the soil sieved through $0.2 \mathrm{~mm}$ sieve for organic carbon content analysis. The processed samples were 
stored in an airtight plastic container. Sub-samplings drawn were frozen for assessing microbial population namely bacteria, fungi, actinobacteria. The soil initial physico-chemical characteristics were assessed based on the method described by Black et al. ${ }^{32}$.

\section{Total aquaregia extractable concentration of heavy metals}

About $2 \mathrm{~g}$ of soil was taken in a conical flask and soaked with $15-20 \mathrm{ml}$ aqua regia (mixture of $\mathrm{HCl}$ and $\mathrm{HNO}_{3}$ in the ratio $3: 1)$. The contents were kept for wet digestion overnight. Hot-plate digestions were carried out at $120^{\circ} \mathrm{C}$ until a white-coloured precipitate appeared at the bottom of the conical flask. Next, the contents of the conical flask were rinsed with MilliQ water and filtered through Whatman No. 42 filter paper. After filtration, the contents were transferred to a $25 \mathrm{ml}$ volumetric flask and volume was made up to the mark with MilliQ water ${ }^{33}$. This solution stored at $4^{\circ} \mathrm{C}$ was analysed for its metal content using atomic absorption spectroscopy manufactured by (model specter AA200, Varian). Air-acetylene mixture was aspired for flame formation; Table 2 lists the instrumental conditions.

\section{Water-soluble fraction}

The water-soluble fraction or bioavailable fraction of metals was assessed based on the method described by Avduainayagam et al. ${ }^{33}$. For this, $10 \mathrm{~g}$ soil and $25 \mathrm{ml}$ of double-distilled water were transferred to polyethylene centrifuge tubes of $40 \mathrm{ml}$ capacity. The soil solution was shaken in an end-to-end shaker at room temperature $\left(25^{\circ} \pm 2^{\circ} \mathrm{C}\right)$ for $6 \mathrm{~h}$ for water-soluble metals. Next, the tubes with the contents were centrifuged at $10,000 \mathrm{rpm}$ for $10 \mathrm{~min}$ and the supernatant, filtered using Whatman No. 42 filter paper ${ }^{33}$ and collected in a pre-cleaned polycarbonated container.

\section{Exchangeable fraction}

The soil residue was obtained after water soluble fraction was weighted for exchangeable fraction. Next, $1 \mathrm{M} \mathrm{Ca}$ $\left(\mathrm{NO}_{3}\right)_{2}$ was added to the centrifuge tube containing soil residue (in the ratio $1: 2.5$ ), and shaken for $4 \mathrm{~h}$ in an

Table 2. Instrumental condition

\begin{tabular}{lccc}
\hline Metal & Type of flame & Wavelength $(\mathrm{nm})$ & Slit width (nm) \\
\hline Cadmium $(\mathrm{Cd})$ & Oxidizing & 228.8 & 0.5 \\
Chromium $(\mathrm{Cr})$ & Reducing & 358.1 & 0.2 \\
Lead $(\mathrm{Pb})$ & Oxidizing & 217.0 & 1.0 \\
Nickel $(\mathrm{Ni})$ & Oxidizing & 341.5 & 0.2 \\
\hline
\end{tabular}

end-to-end shaker for extraction of exchangeable fraction of heavy metals ${ }^{33}$. The rest of the method followed was same as that described for the water-soluble faction.

\section{Bioavailable factor}

Potential toxicity of heavy metals was calculated using bioavailable factor (BF), as described by de Carvalho Damasceno et al. ${ }^{34}$.

$$
\mathrm{BF}=\frac{\text { Bioavailable concentration }}{\text { Total concentration }} \times 100 \text {. }
$$

Bioavailable concentration $=$ water soluble +

exchangeable concentration $\left(\mathrm{mg} \mathrm{l}^{-1}\right)$.

\section{Organic carbon content of soil}

Less than $2 \mathrm{~g}$ of soil was transferred to a $250 \mathrm{ml}$ conical flask. Carbon in the soils was assessed using wet oxidation method by adding $\mathrm{K}_{2} \mathrm{Cr}_{2} \mathrm{O}_{7}$ and concentrated $\mathrm{H}_{2} \mathrm{SO}_{4}$ followed by concentrated $\mathrm{H}_{3} \mathrm{PO}_{4}$ to complete the oxidation process, as described by Walkley and Black ${ }^{35}$.

\section{Analysis of soil PAHS}

The following 15 PAHs were analysed in the soil: naphthalene (Nap), acenaphthlene (Ace), fluorene (Fl), phenanthrene (Phe), anthracene (An), fluoranthene (Flu), pyrene $(\mathrm{Py})$, benz $(\alpha)$ anthracene $(\mathrm{B} \alpha \mathrm{A})$, chrysene $(\mathrm{Cy})$, (benzo $(\beta)$ fluoranthene $(\mathrm{B} \beta \mathrm{F})$, benzo(k)fluoranthene $(\mathrm{BkF})$, benzo $(\alpha)$ pyrene $(\mathrm{B} \alpha \mathrm{P})$, dibenz(a,h)anthracene (Da,hA), benzo(ghi)pyrene (BghiP) and indeno(1,2,3-cd)pyrene $(\mathrm{I} 1,2,3 \mathrm{cdP})$. All chemicals and reagents were purchased from Sigma Aldrich. The soil extract was mixed with methylene chloride $(1: 1 \mathrm{v} / \mathrm{v})$ by manual vigorous shaking for $90 \mathrm{sec}$ and kept for $2 \mathrm{~h}$ at room temperature for separating the solvent layer. The extracted organic phase was dried over anhydrous sodium sulphate and concentrated to $2 \mathrm{ml}$ using a rotary vaccum evaporator. PAHs were analysed using gas chromatographs with ion trap detector (Thermo Scientific), according to the US EPA $8270 \mathrm{C}$ method $^{23,36}$. Standard stock solution (1000 $\mathrm{mg}^{-1}$ ) was prepared by dissolving $10 \mathrm{mg}$ of PAHs in $10 \mathrm{ml}$ $\mathrm{CH}_{3} \mathrm{CN}$ and stored at $-20^{\circ} \mathrm{C}$. Working solutions were prepared fresh daily by serial dilution technique. Using gas chromatography, the PAHs were separated in a $30 \mathrm{~m}$ high-resolution capillary coloumn with a $0.25 \mu \mathrm{m}$ film. The following temperature regime was maintained during the analysis: $50^{\circ}-70^{\circ}, 70^{\circ}-115^{\circ}, 115^{\circ}-175^{\circ}, 175^{\circ}-300^{\circ}$ and $300^{\circ}-450^{\circ} \mathrm{C}$. The calibration was done by external standard methods, using a certified PAH mixture (Sigma Aldrich with $96 \%$ purity). Internal standards were 
Table 3. Initial characterization of sewage-drained soils of major cities in Tamil Nadu

\begin{tabular}{|c|c|c|c|c|c|}
\hline Parameters & $\begin{array}{l}\text { Ukkadam } \\
(n=14)\end{array}$ & $\begin{array}{l}\text { Avanaiayapuram } \\
\qquad(n=14)\end{array}$ & $\begin{array}{l}\text { Rettamalai } \\
\quad(n=12)\end{array}$ & $\begin{array}{l}\text { Koyambedu } \\
\qquad(n=9)\end{array}$ & $\begin{array}{c}\text { Nesapakkam } \\
\quad(n=11)\end{array}$ \\
\hline Bulk density ( $\left.\mathrm{mg} \mathrm{m}^{-3}\right)$ & 1.18 & 1.29 & 1.13 & 1.09 & 1.11 \\
\hline Particle density $\left(\mathrm{mg} \mathrm{m}^{-3}\right)$ & 2.61 & 2.58 & 2.24 & 2.55 & 2.24 \\
\hline $\mathrm{pH}$ & 7.69 & 7.21 & 8.5 & 7.46 & 7.55 \\
\hline $\mathrm{EC}\left(\mathrm{dS} \mathrm{m} \mathrm{m}^{-1}\right)$ & 0.55 & 1.13 & 0.87 & 0.98 & 0.89 \\
\hline $\mathrm{CEC}\left(\operatorname{cmol}\left(\mathrm{p}^{+}\right) \mathrm{kg}^{-1}\right)$ & 14.03 & 17.46 & 24.54 & 27.14 & 22.29 \\
\hline OC $(\%)(n=10)$ & 0.25 & 0.27 & 0.05 & 0.05 & 0.02 \\
\hline Total N $\left(\mathrm{g} \mathrm{kg}^{-1}\right)$ & 0.10 & 0.21 & 0.05 & 0.03 & 0.04 \\
\hline Total P $\left(\mathrm{g} \mathrm{kg}^{-1}\right)$ & 0.02 & 0.041 & 0.013 & 0.01 & 0.01 \\
\hline Total $\mathrm{K}\left(\mathrm{g} \mathrm{kg}^{-1}\right)$ & 0.013 & 0.23 & 0.069 & 0.01 & 0.02 \\
\hline Available $\mathrm{N}\left(\mathrm{kg} \mathrm{ha}^{-1}\right)$ & 255 & 296 & 237 & 240 & 220 \\
\hline Available $\mathrm{P}\left(\mathrm{kg} \mathrm{ha}^{-1}\right)$ & 69 & 55 & 18.8 & 33 & 37.41 \\
\hline Available $\mathrm{K}\left(\mathrm{kg} \mathrm{ha}^{-1}\right)$ & 247 & 280 & 254 & 190 & 200 \\
\hline Total Ca $(\%)$ & 1.55 & 1.21 & 2.14 & 1.16 & 1.81 \\
\hline Total Mg (\%) & 0.90 & 1.43 & 1.22 & 1.55 & 1.33 \\
\hline Total Na $(\%)$ & 0.15 & 0.31 & 2.51 & 3.54 & 4.01 \\
\hline Exchangeable $\mathrm{Ca}\left(\mathrm{cmol}(\mathrm{p}+) \mathrm{kg}^{-1}\right)$ & 3.15 & 2.49 & 8.60 & 5.13 & 5.90 \\
\hline Exchangeable $\mathrm{Mg}\left(\mathrm{cmol}(\mathrm{p}+) \mathrm{kg}^{-1}\right)$ & 1.87 & 2.88 & 4.50 & 6.54 & 6.96 \\
\hline Exchangeable $\mathrm{Na}\left(\mathrm{cmol}(\mathrm{p}+) \mathrm{kg}^{-1}\right)$ & 2.00 & 1.32 & 4.80 & 7.98 & 6.13 \\
\hline Bacteria $\times 10^{6}$ & 24.5 & 18.75 & 12.17 & 6.0 & 8.55 \\
\hline Fungi $\times 10^{4}$ & 10.11 & 8.23 & 5.38 & 2.0 & 2.0 \\
\hline Actinomycetes $\times 10^{3}$ & 2.52 & 1.45 & 1.32 & 1.0 & 1.0 \\
\hline
\end{tabular}

$n$, Number of samples subjected to analysis.

anthracene, pyrene and benzo $\alpha$ pyrene, used to monitor loss of PAHs during extraction and clean-up. For quality control, experiments on recovery were carried out by spiking a known concentration of PAHs (10 and $20 \mathrm{mg} \mathrm{l}^{-1}$ ) with contaminated soil. The results show significant recovery of $89 \% \pm 11 \%$. Percentage of residual standard deviation was $2 \%$ throughout the experiment. The accuracy and precision of the whole chromatographic procedure was checked in every ten samples by injecting known standard and solvent blank.

\section{Analysis of insecticides}

Ten grams of processed soil sample was transferred to a $50 \mathrm{ml}$ centrifuge tube. Next, $20 \mathrm{ml}$ of acitonitrile was added and shaken well by vortex mixture, followed by $\mathrm{MgSO}_{4}$ and $1 \mathrm{~g} \mathrm{NaCl}$ mixed thoroughly and centrifuged. After centrifugation, the supernatant was transferred to a $15 \mathrm{ml}$ centrifuge tube containing $600 \mathrm{mg} \mathrm{MgSO}_{4}+100 \mathrm{mg}$ PSA (primary secondary amine) $+10 \mathrm{mg}$ GCB (graphatized carbon). The contents were mixed and centrifuged for $10 \mathrm{~min}$; then $4 \mathrm{ml}$ of the solution was transferred to a glass tube and concentrated to $1 \mathrm{ml}$ (ref. 37).

\section{Data analysis}

Data collected during the experiments were analysed by employing descriptive statistical tools available in the Microsoft Excel. Correlations among parameters were at 95\% significant level.

\section{Results and discussion}

The initial physico-chemical parameters of studied soils of all five sites were normal for raising agricultural crops (Table 3). Microbial populations of bacteria, fungi and actinobacteria in the sewage soils were active as they formed colonies according to their incubation time. Total aqua regia-extractable heavy metal concentration in soils of all sewage-irrigated sites was within the limits set by Austria and Germany, as well as the Central Pollution Control Board of India (Table 4). However, Cd concentration exceeded the recommended level $\left(3 \mathrm{mg} \mathrm{kg}^{-1}\right.$ in soil) in the Ukkadam site, which has been irrigated with sewage effluent for more than 90 years. The vicinity of Coimbatore that houses more than 500 textile mills, 200 electroplating industries, 300 dyeing units and 100 foundries, releases cocktail mixtures of heavy metals $(\mathrm{Cd}, \mathrm{Cr}$, $\mathrm{Pb}$ and $\mathrm{Ni}$ ) and organic contamination. Among these metals $\mathrm{Cd}$ and $\mathrm{Cr}$ are the major constituents with concentrations exceeding recommended levels in the soil ${ }^{38}$. However, four heavy metals were screened in the present study, viz. $\mathrm{Cd}, \mathrm{Cr}, \mathrm{Pb}$ and $\mathrm{Ni}$. Their bioavailable fraction was also assessed for potential toxicity in soil biota (Tables 5 and 6). The average data on aqua regiaextractable concentration of heavy metals showed that in the soil of Ukkadam, $\mathrm{Pb}$ accumulation was followed by $\mathrm{Cr}, \mathrm{Ni}$ and $\mathrm{Cd}$. In soils of Avaniyapuram, Ni accumulation was followed more by $\mathrm{Cr}, \mathrm{Pb}$ and $\mathrm{Cd}$. In the soils of Rettamalai, $\mathrm{Cr}$ accumulation was followed more by $\mathrm{Pb}$, $\mathrm{Ni}$, and $\mathrm{Cd}$. In soils of Koyambedu, $\mathrm{Pb}$ accumulation was followed more by $\mathrm{Cr}, \mathrm{Cd}$, and $\mathrm{Ni}$. In Nesapakkam soils, 

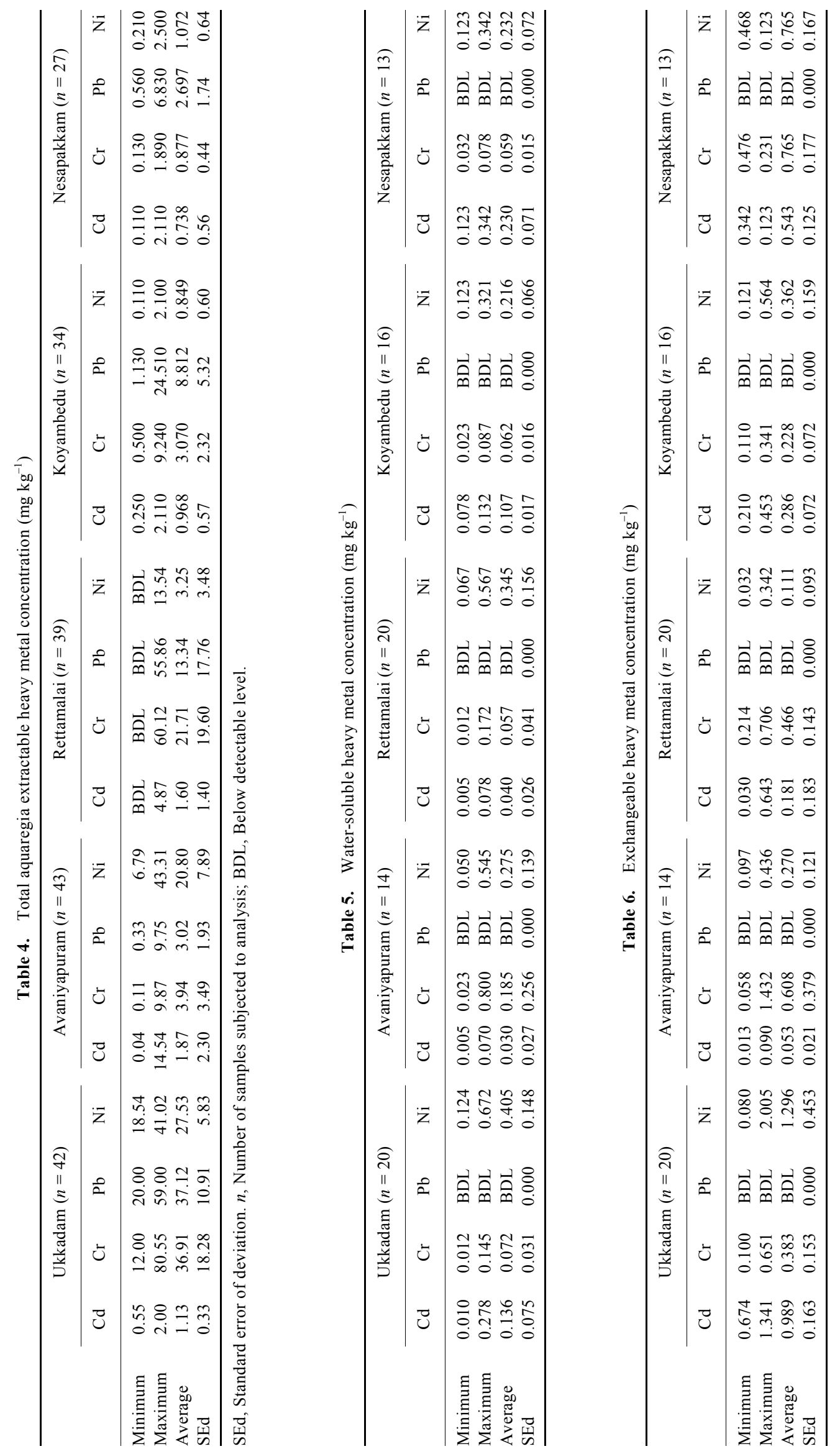
Table 7. Soil carbon content $\left(\mathrm{g} \mathrm{kg}^{-1}\right)$ of sewage drained sites in Tamil Nadu

\begin{tabular}{lccccc}
\hline & Ukkadam & Avaniyapuram & Rettamalai & Koyambedu & Nesapakkam \\
\hline Minimum & 0.19 & 0.26 & 0.04 & 0.03 & 0.02 \\
Maximum & 0.38 & 0.39 & 0.06 & 0.06 & 0.04 \\
Average & 0.27 & 0.32 & 0.05 & 0.04 & 0.04 \\
SEd & 0.44 & 0.35 & 0.06 & 0.09 & 0.06 \\
\hline
\end{tabular}

Number of the samples analysed was 19 for each site.

Table 8. Correlation $\left(r^{2}\right)$ between total aquaregia extractable, water soluble and exchangeable concentration to soil organic carbon content

\begin{tabular}{|c|c|c|c|c|c|c|c|c|c|c|c|c|c|c|c|}
\hline & \multicolumn{3}{|c|}{ Ukkadam } & \multicolumn{3}{|c|}{ Avaniyapuram } & \multicolumn{3}{|c|}{ Rettamalai } & \multicolumn{3}{|c|}{ Koyambedu } & \multicolumn{3}{|c|}{ Nesapakkam } \\
\hline & $\mathrm{T}$ & W & $\mathrm{E}$ & $\mathrm{T}$ & W & $\mathrm{E}$ & $\mathrm{T}$ & W & $\mathrm{E}$ & $\mathrm{T}$ & W & $\mathrm{E}$ & $\mathrm{T}$ & W & $\mathrm{E}$ \\
\hline $\mathrm{Cr}$ & -0.25 & 0.070 & -0.31 & -0.11 & 0.046 & 0.170 & -0.05 & 0.00 & 0.063 & -0.37 & -2.02 & -0.89 & 0.173 & -0.66 & -0.69 \\
\hline $\mathrm{Pb}$ & 0.042 & 0.00 & 0.00 & 0.018 & 0.00 & 0.00 & -0.02 & 0.00 & 0.000 & 0.305 & 0.00 & 0.00 & 0.075 & 0.00 & 0.00 \\
\hline $\mathrm{Ni}$ & -0.14 & -0.2 & -0.15 & 0.125 & -0.03 & -0.1 & -0.7 & -0.23 & 0.055 & -0.32 & -1.112 & 0.193 & -0.08 & -0.24 & -0.45 \\
\hline
\end{tabular}

T, Total aqua regia-extractable concentration; W, Water-soluble concentration; E, Exchangeable concentration; $r^{2}=$ Coefficient of correlation significant at $P<0.05$.

$\mathrm{Pb}$ accumulation was followed more by $\mathrm{Ni}, \mathrm{Cr}$ and $\mathrm{Cd}$. With regard to water-soluble concentration, Ni was more among the four metals in Ukkadam soils, followed by Rettamalai, Avaniyapuram, Nesapakkam and Koyambe$\mathrm{du}$, followed by $\mathrm{Cd}, \mathrm{Cr}$ and $\mathrm{Pb}$ concentrations which were found invariably in all the five sites of sewage drained soils. In the exchangeable fraction of heavy metals, $\mathrm{Ni}$ was quantified higher followed by $\mathrm{Cd}, \mathrm{Cr}$ and $\mathrm{Pb}$ (Table $6)$. In the case of $\mathrm{Pb}$, both the water-soluble and exchangeable fractions were quantified as below detectable concentration in all the sites. Chemically the metal $\mathrm{Pb}$ most often, tightly bound as oxide form was not easily extractable by the $1 \mathrm{M}$ extractant. Hence the water soluble and exchangeable $\mathrm{Pb}$ were below detectable levels in sewage soils $^{39,40}$. Generally, $\mathrm{Pb}$ is found as oxides of soil clay minerals, which strongly bind with oxides and hydroxides of $\mathrm{Fe}$ and $\mathrm{Mn}$. For example, about $0.11 \%-8.3 \%$ of $\mathrm{Pb}$ was reported to be tightly bound with $\mathrm{Fe}$ and $\mathrm{Mn}$ oxide in sandy loam soils ${ }^{39,40}$; hence exchangeable $\mathrm{Pb}$ was not detected in any of the soil solutions in the present. However, the bioavailability of $\mathrm{Pb}$ and similar metals was influenced by soil $\mathrm{pH}$, organic matter and clay content ${ }^{41}$. In general, mobilization of heavy metals is mostly governed by soil microbial activities and soil redox condition $^{42}$. Soil fertility level and organic matter also influence microbial activity ${ }^{43}$. The availability of cationic nutrients were significantly correlated $(86 \%)$ with the presence of organic carbon of the sewage soils ${ }^{44}$. However, the correlation between water-soluble and exchangeable $\mathrm{Cd}, \mathrm{Cr}, \mathrm{Pb}$ and $\mathrm{Ni}$ to organic carbon content was not significant in the present study and followed an irregular pattern (Table 8). The soil organic carbon content was high at Avaniyapuram $\left(0.316 \mathrm{~g} \mathrm{~kg}^{-1}\right)$ and Ukkadam $\left(0.270 \mathrm{~g} \mathrm{~kg}^{-}\right.$ $\left.{ }^{1}\right)$. However, this has no significant role in the bioavailable fraction of metals in those soils (Table 7).
The average carbon content in soils of Avaniyapuram was high, followed by Ukkadam, Rettamalai, Koyambedu and Nesapakkam soils. High organic matter content was reported to decrease concentration of some heavy metals ${ }^{45}$, particularly $\mathrm{Cd}$ and $\mathrm{Ni}^{46}$. In soil, the major determining factor to regulate bioavailability is organic carbon content, which could chelate the free ionic form of cationic elements ${ }^{43}$ due to affinity towards transition metal cations forming stable complexes with organic ligands ${ }^{47}$. As the availability of metal concentration increases, toxicity to soil biota increases exponentially ${ }^{48}$. The other determining factor to regulate metal availability is soil clay content. The clay content of the soil was relatively low in Rettamalai, Koyambedu and Nesapakkam sites.

Bioavailability potential was measured by $\mathrm{BF}$, which was more for $\mathrm{Cd}$ in Ukkadam $(2.9 \%-83 \%)$ followed by $\mathrm{Cr}(1.1 \%-62.3 \%)$ and $\mathrm{Ni}(1.7 \%-52.7 \%)$ in Nesapakkam. Potential bioavailability of these metals in sewagedrained sites was as follows: $\mathrm{Cd}-\mathrm{N}>\mathrm{U}>\mathrm{K}>\mathrm{R}>\mathrm{A}$; $\mathrm{Cr}-\mathrm{N}>\mathrm{A}>\mathrm{K}>\mathrm{R}>\mathrm{U} ; \quad \mathrm{Pb}-\mathrm{N}>\mathrm{K}>\mathrm{R}>\mathrm{U}>\mathrm{A}$ and $\mathrm{Ni}-\mathrm{N}>\mathrm{K}>\mathrm{R}>\mathrm{U}>\mathrm{A}$ (Figure 2). The bioavailable fractions of all four metals were more in Nesapakkam followed by Koyambedu, Rettamalai, Ukkadam and Avaniayapuram. The bioavailability of metals followed a reverse trend with total metal concentration in all five sites. Thus, when the total metal concentration was high, bioavailability was less, and vice versa. This is evident from the per cent BF calculated for all sites (Figure 3): Cd: $99.58 \%$; Cr: $1.23 \%$ and $\mathrm{Ni}: 6.17 \%$ in Ukkadam, $\mathrm{Cd}$ : 4.43\%, Cr: $20.12 \%$ and $\mathrm{Ni}: 2.62 \%$ in Avaniyapuram; $\mathrm{Cd}$ : 13.81\%, Cr: $2.40 \%, \mathrm{~Pb}: 0 \%$ and $\mathrm{Ni}: 14.03 \%$ in Rettamalai; $\mathrm{Cd}: 40.59 \%$, $\mathrm{Cr}: 3.44 \%, \mathrm{~Pb}: 0 \%$ and $\mathrm{Ni}: 68.08 \%$ in Koyambedu and Cd: $>100 \%$; Cr: $93.95 \%$ and $\mathrm{Ni}: 93.00 \%$ in Nesapakkam. Based on BF for $\mathrm{Cd}, 41 \%-99 \%$ was 
RESEARCH ARTICLES

\begin{tabular}{|c|c|c|c|c|c|}
\hline $\begin{array}{l}\text { Organochlorine } \\
\text { compounds (13) }\end{array}$ & $\begin{array}{l}\text { Amount detected } \\
\qquad\left(\mathrm{mg} \mathrm{kg}^{-1}\right)\end{array}$ & $\begin{array}{l}\text { Organophosphates } \\
\qquad(10)\end{array}$ & $\begin{array}{l}\text { Amount detected } \\
\left(\mathrm{mg} \mathrm{kg}^{-1}\right)\end{array}$ & $\begin{array}{c}\text { Synthetic } \\
\text { pyrethroides (8) }\end{array}$ & $\begin{array}{l}\text { Amount detected } \\
\left(\mathrm{mg} \mathrm{kg}^{-1}\right)\end{array}$ \\
\hline$\alpha-\mathrm{HCH}$ & $\mathrm{BDL}(<0.01)$ & Dichlrorovos & BDL $(<0.05)$ & Bifenthrin & BDL $(<0.1)$ \\
\hline$\beta$-HCH & $\mathrm{BDL}(<0.01)$ & Phorate & BDL $(<0.05)$ & Fenpropathrin & $\operatorname{BDL}(<0.1)$ \\
\hline$\gamma-\mathrm{HCH}$ & $\operatorname{BDL}(<0.01)$ & Dimethoate & BDL $(<0.05)$ & $\lambda$-Cyhalthrin & $\operatorname{BDL}(<0.1)$ \\
\hline Dicofol & $\operatorname{BDL}(<0.01)$ & Malathion & $\operatorname{BDL}(<0.05)$ & $\alpha$-Cypermethrin & $\operatorname{BDL}(<0.1)$ \\
\hline Endosulfan- $\alpha$ & BDL $(<0.01)$ & Chloropyriphos & BDL $(<0.05)$ & Fenvalerate & $\operatorname{BDL}(<0.1)$ \\
\hline Endosulfan- $\beta$ & $\mathrm{BDL}(<0.01)$ & Quinolphos & $\mathrm{BDL}(<0.05)$ & Fluvalinate & $\operatorname{BDL}(<0.1)$ \\
\hline Endosulfan sulfate & BDL $(<0.01)$ & Profenophos & BDL $(<0.05)$ & Deltamethrin & $\operatorname{BDL}(<0.1)$ \\
\hline$p, p^{\prime}-\mathrm{DDD}$ & $\operatorname{BDL}(<0.01)$ & Ethion & BDL $(<0.05)$ & & \\
\hline$p, p^{\prime}-\mathrm{DDT}$ & $\mathrm{BDL}(<0.01)$ & Triazophos & $\mathrm{BDL}(<0.05)$ & & \\
\hline$p, p^{\prime}-\mathrm{DDE}$ & $\mathrm{BDL}(<0.01)$ & & & & \\
\hline Heptachlor endoepoxide & $\operatorname{BDL}(<0.01)$ & & & & \\
\hline
\end{tabular}
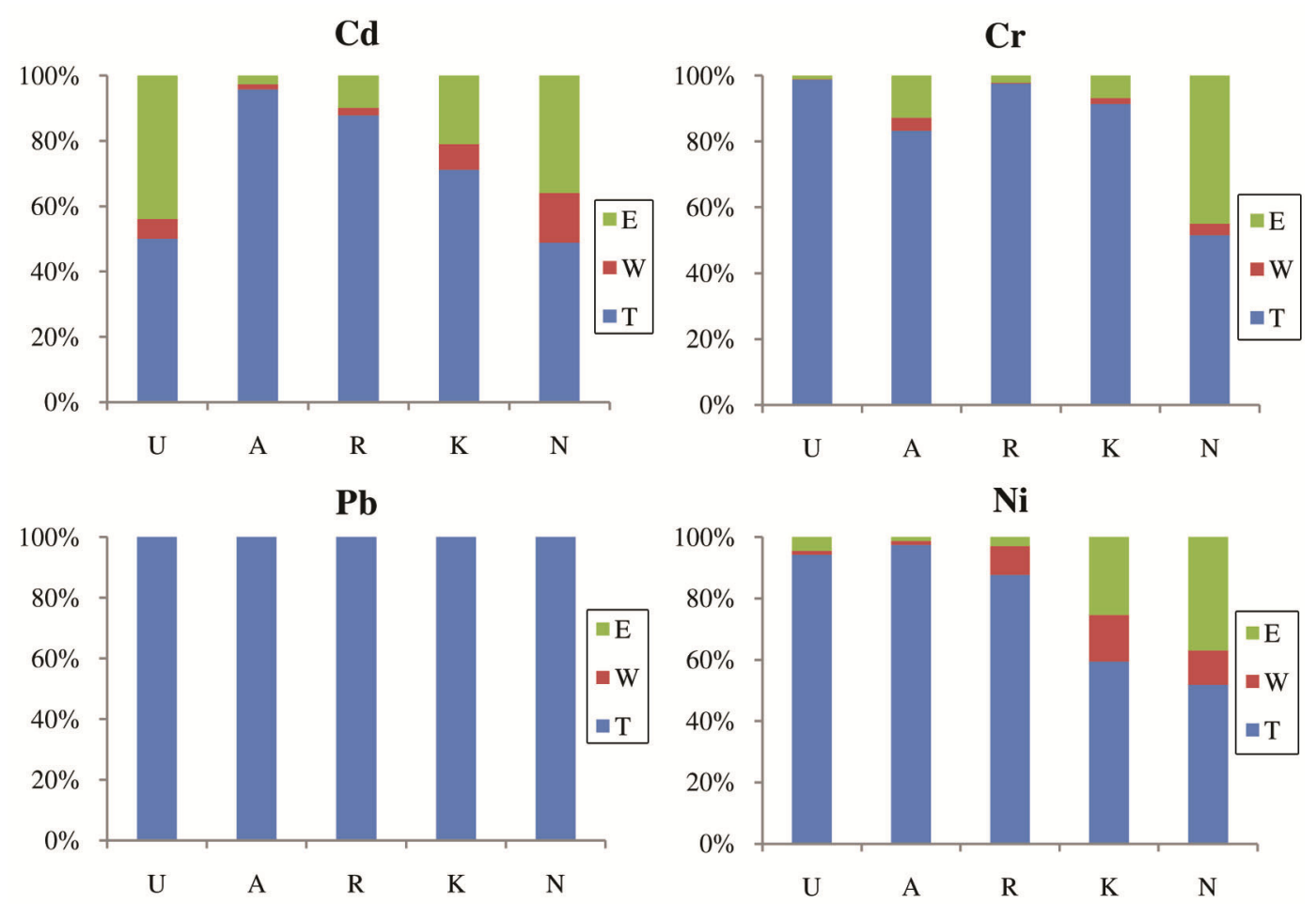

Figure 2. Potential bioavailability of heavy metals. U, Ukkadam; A, Avaniapuram; R, Rettamalai; K, Koyambedu; N, Nesapakkam; T, Total concentration; W, Water soluble concentration and E, Exchangeable concentration.

bioavailable from the total metal concentration of $2 \mathrm{mg} \mathrm{kg}^{-1}$ in soil. Higher concentration accumulated only in Avaniyapuram soil and its BF was low (2.9\%). Hence, all $\mathrm{Cd}$ present in the soils is in bioavilable form. Similar trends were observed for $\mathrm{Ni}, \mathrm{Cd}$ and $\mathrm{Cr}$ in Nesapakkam soils. In Nesapakkam soils too, the concentrations of $\mathrm{Cd}$ and $\mathrm{Ni}$ are bioavailable due to their weak binding to soil exchangeable sites ${ }^{33}$. Though total soil $\mathrm{Pb}$ content was significant, its bioavailability was below detectable level in all five sites, in contrast with other metals. This may be because $\mathrm{Pb}$ is tightly bound with $\mathrm{Fe}$ and $\mathrm{Mn}$ oxide form $^{39,40}$. Cr and Ni were higher in Ukkadam followed by
Avaniyapuram, Rettamalai, Koyambedu and Nesapakkam soils; their bioavailability concentration was low. $\mathrm{Cr}$ and $\mathrm{Ni}$ are strongly bound with carbonate and bicarbonate, Fe and $\mathrm{Mn}$ oxide and residual fraction, and hence may not be easily released in the soil solution ${ }^{33,49}$.

In addition to organic matter, clay content of soils also determines the availability of heavy metals ${ }^{44,46,47,50}$. Soil organic matter and clay content of the soils of Rettamalai, Koyambedu and Nesapakkam had a positive influence on the total metal content, as their total aqua regiaextractable concentrations were higher in those soils; hence, most of them were tightly bound by carbonate, 


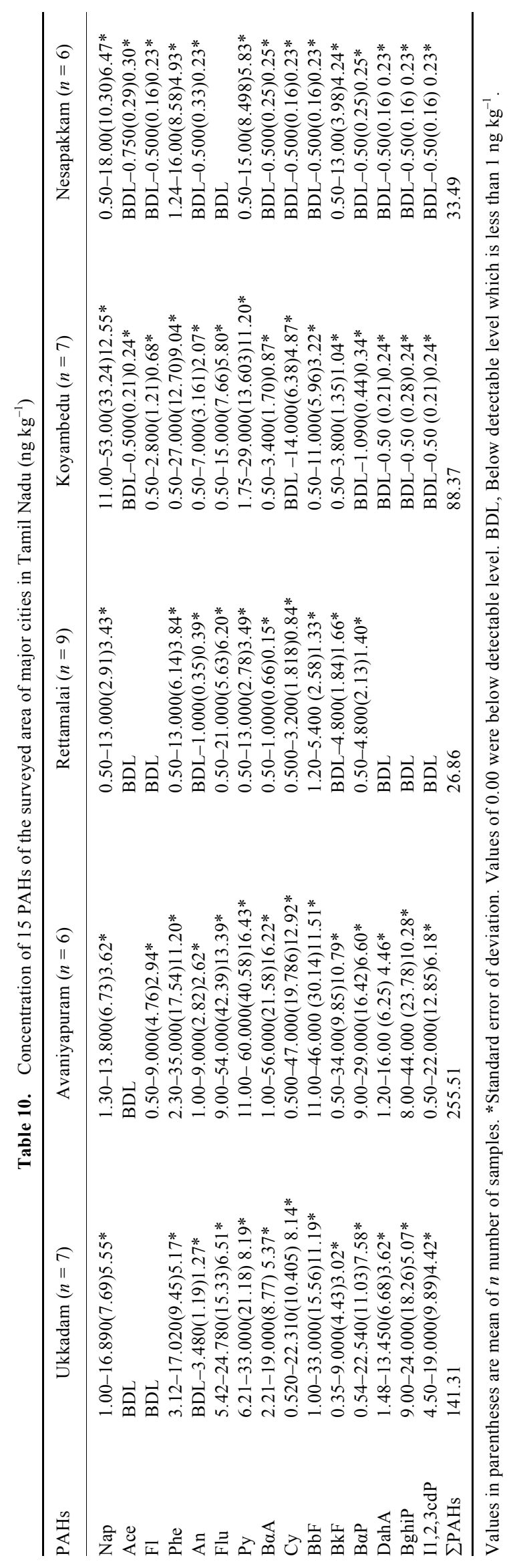




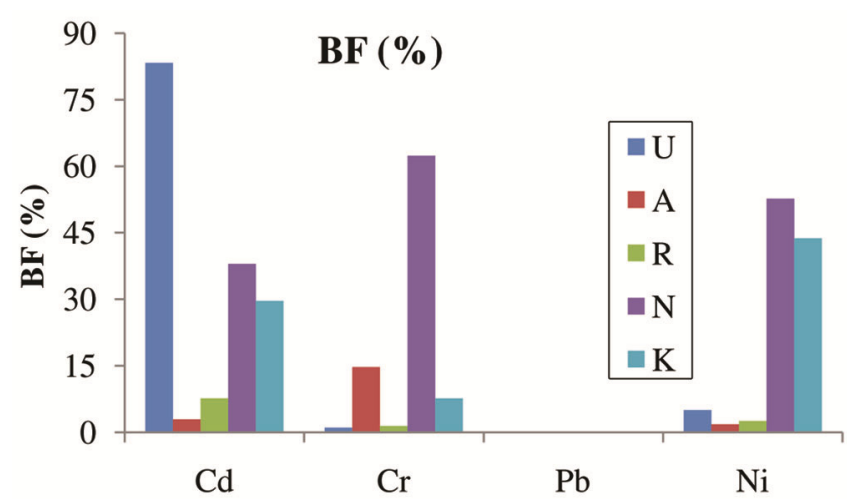

Figure 3. Bioavailable factors (BFs) of $\mathrm{Cd}, \mathrm{Cr}, \mathrm{Pb}$ and $\mathrm{Ni}(\%)$.

bicarbonate mineral fraction and iron aluminum hydroxide $^{40}$. Following the heavy metal assessment, the soil was screened for insecticides and PAHs. Thirty-one insecticides belonging to various groups of organophosphorous, organochlorine and synthetic pyrithroid groups were analysed as they were below detectable concentration (at $\mathrm{ng} \mathrm{kg}^{-1}$ level) and it is evident that the sewage effluents may not transport (Table 9). In case of PAHs, their sources are incomplete burning of fossil fuels, aerial deposition and vehicular emission ${ }^{49}$. However, sewage effluent itself transports a large amount of PAHs. In China, about $1.9 \times 10^{4}$ ha of farmland was reported to be contaminated by PAHs due to long-term sewage irrigation $^{14}$. In the present study, 15 out of the PAHs present in 16 US EPA priority list have been identified. The toxic properties of PAHs arise due to their low solubility in water; also the very meagre longer half-life in soil gives them longer persistence in the environment (Table 1). Total PAHs were more in Avaniyapuram followed by Ukkadam, Koyambedu, Nesapakkam and Rettamalai (Table 10). Among the 15 PAHs, Ace and Fl were not detected in soils of Ukkadam, Avaniyapuram and Rettamalai. Ace and Fl were detected in maximum concentration in Koyambedu and Nesapakkam soils. Generally high molecular weight PAHs (3-6 rings) were accumulated more compared to two-ring PAHs. In Koyambedu and Nesapkkam, high molecular weight PAHs were quantified. The samples containing PAHs below detectable limits were reanalysed in order to obtain the concurrent values. The repeat analysis too reported below detectable limits. Nevertheless, for low molecular weight PAHs, Ac was not detected in any of the samples. The results of PAH contamination in sewage-drained soils suggest that continuous monitoring is essential to ensure their safe concentration in the soil.

\section{Conclusion}

- The data of this study show that $\mathrm{Cd}, \mathrm{Cr}, \mathrm{Pb}$ and $\mathrm{Ni}$ are more in Avanaiyapuram followed by Ukkadam, Rettamalai, Koymbedu and Nesapakkam sewage soils.
- The concentrations of all four metals in the soils were within safe limits $(\mathrm{Cd}=1-5 ; \mathrm{Cr}=100 ; \mathrm{Pb}=100$; $\mathrm{Ni}=75 \mathrm{mg} \mathrm{kg}^{-1}$ ) in agreement with WHO recommendation for raising agricultural crops; however, their availability showed potential risk of accumulation in higher trophic of the food chain.

- Fifteen individuals were screened among 16 US EPA priority PAHs. High molecular weight PAHs were accumulated more in soils of all sites; however, their concentration was within safe limits $\left(0.3 \mathrm{mg} \mathrm{kg}^{-1}\right)$, according to WHO standards.

- The assessment of bioavailable fraction of heavy metals are the significant outcome of the present research. The bioavailable concentrations are toxic to soil biota microbial activities and overall soil health.

\section{Future research}

- Area under sewage irrigation in and around city limits must be delineated, while it is a common practice followed in economically weaker countries since globalization. Hence, such areas are to be clearly demarcated, as is done for sites contaminated by industries. Only then soil reclamation can be implemented in such a polluted site.

- Heavy metals in sewage contaminated soils studied only few elements in a limited area. But complete screening of metal pollution along with organic chemical substances are to be carried out in possible sewage drained soils. For example, arsenic is used for manufacturing pesticides and is also reported in fertilizers. Mercury is detected in sewage effluents. Hence, the assessment of number of metals in a contaminated site is important. This will facilitate implementation of reclamation measures for the identified sites. The present study only focus on four metals and organics like few PAHs and insecticides. However, inclusion of other metals and organic contaminants would be the future thrust area of mixed contamination research.

- Sewage effluent was reported to contain chemicals from various sources: pharmaceutical chemicals, veterinary chemicals, personal-care products, industries, etc. Hence, complete screenings of different groups of organic contamination are to be carried out in sewage soils around cities.

- Future prospects in the field of sewage-contaminated soils can screen mixed contaminants, broadly organic (as mentioned above) and inorganic chemicals around large cities of Tamil Nadu, and their impact on soil and human health.

1. Strauss, M. and Blumenthal, U., Human waste use in agriculture and aquaculture: utilization practice and health perspectives. IRCWD Report 09/90, International Reference Centre for Waste Disposal, Duebendorf, Germany, 1990. 
2. https://www.cpursehero.com/file/33493434/chp-19-waterpollution-India-An-Economic-Appraisalpdf/

3. http://www.worldometers.info/world-population/india-population/

4. Anon., National Agricultural Technological Project report on 'use of urban and industrial effluent in agriculture', Central Soil Salinity Research Institute, Karnal, 2004.

5. Sengupta, A. K., WHO Guidelines for the safe use of wastewater, excreta and grey water. In National Workshop on Sustainable Sanitation, New Delhi, 19-20 May 2008, http://www.whoindia.org/ LinkFiles/WasteWater Management WHO Guidelines for the safe use of wastewater, excreta_use of wastewater, excreta and greywater.pdf.

6. Datta, A., Schmeits, J. L., Amin, N. S., Lau, P. J., Myung and Kolodner, R. D., Checkpoint-dependent activation of mutagenic repair in Saccharomyces cerevisiae pol3-01 mutants. Mol. Cell. 2000, 6(3), 593-603.

7. Yadav, S. K. Subhash Babu, M. K. Yadav, Kalyan Singh, G. S. Yadav and Suresh Pal, A., Review of organic farming for sustainable agriculture in northern India. Int. J. Agron., 2002; Article ID 718145; http://dx.doi.org/10.1155/2013/718145.

8. Rattan, R. K., Datta, S. P., Chhonkar, P. K., Suribabu, K. and Singh, A. K., Long-term impact of irrigation with sewage effluents on heavy metal content in soils, crops and groundwater - a case study. Agric., Ecosyst. Environment., 2005, 109, 310-322.

9. Preciado, C., Jiménez-Cartagen, D. C., Matamoros, V. and Bayona, J. M., Screening of 47 organic micro contaminants in agricultural irrigation waters and their soil loading. Water Res., 2011, 221-231; doi:10.1016/j.watres.2010.07.050.

10. Wild, S. R., Berrow, M. L. and Jones, K. C., The persistence of polynuclear aromatic hydrocarbons (PAHs) in sewage sludge amended agricultural soils. Environ. Pollut., 1991, 72(2), 141157; https://doi.org/10.1016/0269-7491(91)90064.

11. Andrews, R. J., Lloyd, J. W. and Lerner, D. N., Sewage sludge disposal to agriculture and other options in the UK. In Groundwater Contaminants and their Migration (eds Mather, J. et al.), Geological Society of London, Special Publications, 1998, vol. 128, pp. 63-74.

12. Rogers, H. R., Organic contaminants in sewage sludge. Occurrence and fate of synthetic organic compounds in sewage and sewage sludge - a review. Water Research Centre Report, 1987, PRD 1539-M

13. Wilson, S. C., Duarte-Davidson, R. and Jones, K. C., Screening the environmental fate of organic contaminants in sewage sludges applied to agricultural soils: the potential for downward movement to groundwaters. Sci. Total Environ., 1996, 185, 45-57.

14. Chung, N. J., Cho, J. Y., Park, S. W., Park, B. J., Hwang, S. A. and Park, T. I., Polycyclic aromatic hydrocarbons in soils and crops after irrigation of wastewater discharged from domestic sewage treatment plants. Bull. Environ. Contamin. Toxicol., 2008, 81, 124-127.

15. Li, X. J., Li, P. J., Lin, X., Gong, Z. Q., Fan, S. X., Zheng, L. and Verkhozin, E. A., Spatial distribution and sources of polycyclic aromatic hydrocarbons (PAHs) in soils from typical oil sewage irrigation area, northeast China. Environ. Monit. Assess., 2008, 143, 257-265.

16. Cai, Q. Y., Mo, C. H., Wu, Q. T., Zeng, Q. Y. and Katsoyiannis, A., Occurrence of organic contaminants in sewage sludge from eleven wastewater treatment plants, China. Chemosphere, 2007, 68(9), 1751-1762.

17. ATSDR, Toxicological profile for polycyclic aromatic hydrocarbons. US Department of Health and Human Service, Agency for Toxic Substances and Disease Registry, USA, 1995.

18. Fernández-Alba, A. R., European Union proficiency test for pesticides in fruits and vegetables for screening methods 02 (EUPTFV-SM-02),

19. Kim, K. H., Jahan, S. A., Kabir, E. and Brown, R. J., A review of airborne polycyclic aromatic hydrocarbons (PAHs) and their human health effects. Environ. Int., 2013, 60, 71-80; doi:10.1016/ j.envint.2013.07.019.

20. IARC, International Agency for Research on Cancer, Some nonheterocyclic polycyclic aromatic hydrocarbons and some related exposures. In IARC, Monographs Evalat. Carcinoge. Risks Hum., 2010, 92, 765-771.

21. Khan, S. Aijun, L., Zhang, S., Hu, Q. and Zhu, Y. G., Accumulation of polycyclic aromatic hydrocarbons and heavy metals in lettuce grown in the soils contaminated with long-term wastewater irrigation. J. Hazard. Mater., 2008, 152, 506-515.

22. Zhang, S. et al., Uptake and translocation of polycyclic aromatic hydrocarbons (PAHs) and heavy metals by maize from soil irrigated with wastewater. Sci. Rep., 2017, 7, 12165; doi:10.1038/ s41598-017-12437-w.

23. Wu, W., Huang, H., Ling, Z., Yu, Z., Jiang, Y., Liu, P. and Li, X., Genome sequencing reveals mechanisms for heavy metal resistance and polycyclic aromatic hydrocarbon degradation in Delftia lacustris strain LZ-C Wenyang. Ecotoxicology, 2016, 25(1), 234247; doi:10.1007/s10646-015-1583-9.

24. Huang, H. et al., A novel Pseudomonas gessardii strain LZ-E simultaneously degrades naphthalene and reduces hexavalent chromium. Bioresour. Technol., 2016, 207, 370-378.

25. Xiao, J., Guo, L., Wang, S. and Lu, Y., Comparative impact of cadmium on two phenanthrene-degrading bacteria isolated from cadmium and phenanthrene co-contaminated soil in China. J. Hazard. Mater., 2010, 174, 818-823.

26. Thavamani, P., Malik, S., Beer, M., Megharaj, M. and Naidu, R., Microbial activity and diversity in long-term mixed contaminated soils with respect to polyaromatic hydrocarbons and heavy metals. J. Environ. Manage., 2012, 99, 10-17.

27. Kuppusamy, S., Thavamani, P., Megharaj, M. and Naidu, R., Biodegradation of polycyclic aromatic hydrocarbons (PAHs) by novel bacterial consortia tolerant to diverse physical settings assessments in liquid- and slurry-phase systems. Int. Biodeterior. Biodegrad., 2016, 108, 149-157.

28. Kathavarayan, V., Avudainayagam, S., Doraisamy, P. and Chandraseharan, C. N., Chemical immobilization of lead in long term sewage irrigated soil. J. Agric. Sci. Technol., 2012, 14, 449-458.

29. Chitdeshwari, T., Savithri, P. and Mahimai Raja, S., Effect of sewage bio-solids compost on biomass yield of amaranths and heavy metal availability. J. Indian Soc. Soil Sci., 2002, 50, 480484.

30. Musharafia, A. S. K., Mahmoud, I. Y. and Al-Bahry, S. N., Heavy metal pollution from treated sewage effluent. APCBEE Proc., 2013, 5, 344-348.

31. Chary, S. N., Kamala, C. T. and Raj, D. S. S., Assessing risk of heavy metals from consuming food grown on sewage irrigated soils and food chain transfer. Ecotoxicol. Environ. Saf., 2008, 69, 513-524.

32. Black, C. A., Evans, D. D. Ensminger, L. E. White, J. L., Clark, F. E., Dinauer, R. C., Methods of soil Analysis. Part 2. Chemical and Microbiological Properties, American Society of Agronomy, Madison, Wisconsin, USA, 1965.

33. Avudainayagam, S., Megharaj, M., Owens, G., Kookana, R. S., Chittle Borough, D. and Naidu, R., Chemistry of chromium in soils with particular emphasis on tannery waste contaminated sites: a review. Rev. Environ. Contamin. Toxicol., 2003, 178.

34. de Carvalho Damasceno, O. I., Reis, C., Reis, E. L., Bellato, C. R. and Fidêncio, P. H., Assessment of bioavailability of heavy metals after vermicomposting in the presence of electronic waste. Rev. Bras. Cienc. Solo, 2015, 39, 1786-1795.

35. Walkley, A. and Black, I. A., Estimation method for determination of soil organic matter and a proposed modification of the chromic acid titration method. Soil Sci., 1934, 37, 29-33.

36. EPA US, Environmental Protection Agency, United State. Method 8270C: Semivolatile organic compounds by gas chromatography/mass spectrometry (GC/MS). SW-846, Test methods for eva- 
luating solid waste, physical/chemical methods. United States Environmental Protection Agency, Washington, DC, 1996.

37. Malarkodi, M., Krishnasamy, R., Kumaraperumal, R. and Chitdeshwari, T., Characterization of heavy meal contaminants soils of coimbatore in Tamil Nadu. J. Agron., 2007, 6(1), 147151.

38. Chlopecka, A., Bacon, J. R., Wilson, M. J. and Kay, J., Heavy metals in the environment. J. Environ. Qual., 1996, 25, 69-79.

39. Ramos, L., Hernandez, L. M. and Gonzales, M. J., Sequential fractionation of copper, lead, cadmium and zinc in soil from or near Donana national park. J. Environ. Qual., 1994, 23, 50-57.

40. Bashir, F., Tariq, M., Khan, M. H. Khan, R. A. and Aslam, S., Fractionation of heavy metals and their uptake by vegetables growing in soils irrigated with sewage effluent. Turk. J. Eng. Environ Sci., 2014, 38, 1-10.

41. Fytianos, K., Katsianis, G., Triantafyllou, P. and Zachariadis, G., Accumulation of heavy metals in vegetables grown in an industrial area in relation to soil. Bull. Environ. Contam. Toxicol., 2001, 67, 423-430.

42. Somasundaram, J. et al., Accumulation of few heavy metals in sewage sludges, soils and plants of coimbatore, Tamil Nadu (India). J. Environ. Sci. Eng., 2012, 54(1), 13-29.

43. Sara, P. B. K., Megharaj, M., Juhasz, A. L., Sethunathan, N. and Naidu, R., Chromium-microorganism interactions in soils: remediation implications. Rev. Environ. Contam. Toxicol., 2003, 178, 93-164.

44. Khan, A. G., Kuek, C., Chandhry, T. M., Khoo, C. S. and Hayes, W. J., Role of plants, mycorrhizae and phytochelators in heavy metal contaminated land remediation. Chemosphere, 2000, 41, 197-207.

45. Pendias, K. A. and Pendias, H., Trace Elements in Soils and Plants, CRC Press, New York, USA, 2001.
46. Arnesen, A. K. M. and Singh, B. R., Plant uptake and DTPAextractability of $\mathrm{Cd}, \mathrm{Cu}, \mathrm{Ni}$ and $\mathrm{Zn}$ in a Norwegian alum shale soil as affected by previous addition of dairy and pig manures and peat. Can. J. Soil Sci., 1999, 78, 531-539.

47. Elliot, H. A., Liberati, M. R. and Huang, C. P., Competitive adsorption of heavy metals by soils. J. Environ. Qual., 1986, 15, 214-219.

48. Wang, N., Li, H. B., Long, J. L., Cai, C., Dai, J. L. Zhanga, J. and Wanga, R. Q., Contamination, source, and input route of polycyclic aromatic hydrocarbons in historic wastewater-irrigated agricultural soils. J. Environ. Monit. 2012, 14, 3076.

49. Finžgar, N., Tlustoš, P. and Leštan, D., Relationship of soil properties to fractionation, bioavailability and mobility of lead and zinc in soil. Plant Soil Environ., 2007, 53(5), 225-238.

50. Duan, L., Naidu, R., Thavamani, P., Meaklim, J. and Megharaj, M., Managing long-term polycyclic aromatic hydrocarbon contaminated soils: a risk-based approach. Environ. Sci. Pollut. Res. 2013, 12, 8927-8941; doi:10.1007/s11356-013-2270-0.

51. Coover, M. P. and Sims, R. C., The effect of temperature on polycyclic aromatic hydrocarbon persistence in an unacclimated agricultural soil. Hazard. Waste Hazard. Mater., 1987, 4, 1.

52. Mackay, D., Shiu, W. Y., Ma, K. and Lee, S. C., Handbook of Physical-Chemical Properties and Environmental Fate for Organic Chemicals, CRC Press, Vol. I, 2006.

53. EPA US, Environmental Protection Agency, United State. Provisional guidance for quantitative risk assessment of polycyclic aromatic hydrocarbons. Development, 1993, 1-28.

Received 13 June 2018; revised accepted 10 May 2019

doi: $10.18520 / \mathrm{cs} / \mathrm{v} 117 / \mathrm{i} 3 / 448-459$ 